\title{
PERFORMANCE OF A PILOT PLANT FOR CONDITIONING OF SEPTAGE TO BE TREATED IN A SEWAGE TREATMENT PLANT
}

\author{
DESEMPENHO DE UMA PLANTA PILOTO PARA CONDICIONAMENTO DE LODO DE FOSSA E \\ TANQUE SÉPTICO PARA SER TRATADO EM UMA ESTAÇÃO DE TRATAMENTO DE ESGOTO
}

\author{
Adriane Dias da Silva Lisboa ${ }^{a}$, Yovanka Pérez Ginoris ${ }^{b}$, Marco Antonio Almeida de Souza ${ }^{b}$ \\ ${ }^{a}$ Centro Universitário IESB, ${ }^{b}$ Universidade de Brasília - UnB \\ adrianedias19@gmail.com,yovanka.perez@gmail.com, marcantoniosouza@gmail.com
}

Submissão: 16 de outubro de 2021 Aceitação: 22 de novembro de 2021

\section{Abstract}

This work evaluated the behaviour of a Pilot Plant to receive and pre-treat septage collected and transported by trucks from decentralized sewage treatment systems and greasy residues from grease traps. This Pilot Plant was installed at the Brasília Sul Sewage Treatment Plant and was composed of a grid, equalization tank, rotating screen, crusher and a Central Unit for separating settleable solids (SetS) and floating solids, mainly oils and greases (O\&G). The Central Unit consists of an adaptation of an aerated grit chamber to receive intermittent loads of septage dumped from trucks. The Central Unit was tested in four operating modes to investigate the influence of the presence of greasy residues and aeration in the initial third of the length of its chamber: Mode 1 - Central Unit without aeration and receiving only septage; Mode 2 - Central Unit with aeration and receiving only septage; Mode 3 - Central Unit without aeration and receiving mixtures of greasy residues and septage; and Mode 4 - Central Unit with aeration and receiving mixtures of greasy residues and septage. It was verified that there is a tendency of the Central Unit to behave better when receiving mixtures of septage and greasy residues. Comparing Modes 1 and 2, Mode 2 showed only $6 \%$ more O\&G removal than Mode 1, on average. Comparing Modes 3 and 4, Mode 4 reached 32\% more removal of O\&G than Mode 3 , on average. However, the use of aeration was not statistically significant. The Pilot Plant on average reduced $72 \%$ of O\&G and $90 \%$ of SetS in Modes 1 and 2 , and $95 \%$ of O\&G and $90 \%$ of SetS in Modes 3 and 4.

Keywords: septage; sewage and septage co-treatment; septage management.

\section{Resumo:}

Este trabalho avaliou o comportamento de uma Planta Piloto para recebimento e pré-tratamento de lodo coletado e transportado por caminhões limpa-fossas proveniente de instalações de tratamento de esgoto descentralizado e de resíduos gordurosos de caixas de gordura. Esta Planta Piloto foi instalada na Estação de Tratamento de Esgoto de Brasília-Sul, e era composta por grade, tanque de equalização, peneira rotativa, triturador e uma Unidade Central para separação de Sólidos Sedimentáveis (SSed) e flutuantes, principalmente óleos e graxas (O\&G). A Unidade Central consiste em uma adaptação de uma câmara de areia aerada para receber cargas intermitentes de lodo despejado dos caminhões. A Unidade Central foi testada em quatro modos de operação para investigar a influência da presença de resíduos gordurosos e da aeração no terço inicial do comprimento da sua câmara, a seguir descritos: Modo 1 - Unidade Central sem aeração e recebendo apenas lodos de instalações descentralizadas de esgoto; Modo 2 - Unidade Central com aeração e recebendo apenas lodos de instalações de tratamento de esgoto descentralizado; Modo 3 Unidade Central sem aeração e recebendo misturas de resíduos gordurosos e lodos de instalações de tratamento de esgoto descentralizado; e Modo 4 - Unidade Central com aeração e recebendo misturas de resíduos gordurosos e lodos de instalações de tratamento de esgoto descentralizado. Foi verificado que há uma tendência da Unidade Central em se comportar um pouco melhor ao receber misturas de lodo de instalações de tratamento de esgoto descentralizado e de resíduos gordurosos. Comparando os Modos $1 \mathrm{e}$ 2, o Modo 2 apresentou apenas 6\% de remoção de O\&G a mais do que o Modo 1, em média. Comparando os Modos 3 e 4, o Modo 4 alcançou 32\% a mais do que o Modo 3 na remoção de O\&G, em média. No entanto, 
o uso de aeração não apresentou eficiência estatisticamente significativa. A Planta Piloto inteira reduziu em média $72 \%$ de O\&G e $90 \%$ de SSed nos Modos 1 e 2, e $95 \%$ de O\&G e $90 \%$ de SSed nos Modos 3 e 4, em média.

Palavras-chave: lodo de instalações de tratamento de esgoto descentralizado; cotratamento de esgoto e lodo de instalações de tratamento de esgoto descentralizado; gestão de lodos de fossas e tanques sépticos.

\section{INTRODUCTION}

Most of the population in the suburbs of large cities and the countryside of Brazil use cesspools and septic tanks for the treatment of domestic wastewaters, due to the absence of a sewage collection network in these places. Periodic cleaning of cesspools and septic tanks should be carried out so as not to impair their functioning, which generates septage very often disposed of in inappropriate places, such as rivers, streams and urban rainwater systems, generating a health and environmental problem.

Waste from cleaning the cesspools, septic tanks, and other equipment for on-site sanitation, identified in this work as "waste from septage collection and transport trucks" or simply "waste from septage trucks", does not only contain the solid fraction itself, but also the liquid and supernatant fraction present in the cesspool or septic tank. Often they also contain the greasy residues from cleaning grease traps, faecal sludge and wastes from pits, soakaways and vaults.

In Brazil, companies responsible for cleaning cesspools and septic tanks are usually contracted by the sanitation system user and these companies almost always also clean the grease traps of building facilities when cleaning the building on-site sewage treatment. In large buildings served by the municipal sewage system, residents and building managers also call these companies only to clean the grease traps in the building's sewer system. These companies use vacuum trucks to collect, transport and discharge this waste. These trucks are also called on to clean fat separating equipment from restaurants, gas stations and some industries. This type of waste is called "greasy residue" in this work.

In many cities where the sewage treatment system exists and is efficient, the most recommendable solution, usually, is the overflow of this waste in the Municipal Wastewater Treatment Plant (or the Sewage Treatment Plant - STP), to be treated in combination with the sewage. The decision to treat the discharge of septage trucks as part of the conventional municipal wastewater treatment process can have several significant and deleterious effects. The treatment of this waste input increases the load of liquids and solids in the STP with resulting increases in operating costs, production of solids, handling of solids and costs of disposal or use. The septage discharged into the STP can affect the progress of the STP operation and maintenance and increase the amount of biosolids produced in an installation (AL-SA'ED \& HITHNAWI, 2006; TAYLER, 2018).

When waste from septage trucks is added to the sewage stream, it may impact the STP in several ways, such as: odour issues, especially at the wastes reception area (particularly for fresh septage); increase in the quantity of screenings and grit; increase in sludge and scum; production of significantly higher organic, nitrogen and solids loadings; occurrence of shock loading due to irregular addition of this waste; and potential presence of toxic substances in this type of released waste (NARAYANA, 2020; AL-SA'ED \& HITHNAWI, 2006; LOPEZ-VAZQUEZ et al., 2014).

The presence of O\&G (or "FOG" - Fats, Oils and Grease -, as they are commonly called by the sewage operation personnel) in the septage also causes several inconveniences to the sewage treatment process. For the STP that receives this type of waste, the presence of oils and greases in the waste from septage truck has been a problem, mainly due to the impact that grease can have on the sewage treatment system. The adhesion of $O \& G$ to the pipes and clogging of sieves and filters can hinder the biological treatment of wastewater with a high concentration of O\&G suspended on the surface, thus affecting the unit operations of the STP. In the last stage of the wastewater treatment process, O\&G adheres to the sludge, making it viscous and waxy, thus reducing the efficiency of dewatering this sludge. In addition, O\&G is more difficult to degrade biologically than other common municipal wastewater components. The impact of grease on STPs can include: (1) excessive foam production; (2) problems with Nocardia filaments; (3) increased sludge volume; and (4) production of 
effluent with a high $\mathrm{O} \& \mathrm{G}, \mathrm{BOD}_{5}$ and TSS values. $O \& G$ also causes problems for the operation of grit chambers and sedimentation tanks in STPs (GOWTHAMAN, MAFIZUR \& SIVAKUMAR, 2017; HUSAIN et al., 2014).

In Brazil, the concentration of oils and greases in septage is high, generally above $300 \mathrm{mg} \mathrm{L}^{-1}$ (CAMPOS et al., 2009). The study carried out in Brazil (ANDREOLI, 2009) showed a great variation in the content in samples of septage, including oils and greases, except for $\mathrm{pH}$, which was found with relative constancy.

Specifically for the Federal District of Brazil, the examination of $O \& G$ performed by Silva et al. (2015) in wastes from septage hauler's trucks unloading at the Sewage Treatment Plant of Brasilia located in the Asa Sul region (Brasilia Sul STP) presented a median concentration of $793 \mathrm{mg}$ $\mathrm{L}^{-1}$ of oils and greases. Of all tests carried out on the septage samples from Brasilia Sul STP, the $O \& G$ test was the one with the highest variation coefficients. Half of the septage truck data were gathered between 664 and 2,948 $\mathrm{mg} \mathrm{L}^{-1}$ of $O \& \mathrm{G}$, with a maximum value of $4,774 \mathrm{mg} \mathrm{L}^{-1}$.

Oils and greases can be present in septage in free form, emulsified or adhered to solids. Fats that are in their free form are more easily removed. The treatment can be divided into two phases. The first phase separates free fat (not emulsified) using separation by gravity. The second phase involves the removal of emulsified products, for example, by heating, distillation, chemical treatment and centrifugation, flocculation, dissolved air flotation and filtration. Ultrafiltration has also been used successfully in the recovery of fatty acids (WEF, 2008).

In the Brazilian sewage treatment plant projects, it is not normally foreseen, yet, the release of other wastes, such as septage, faecal sludge and landfill leachate. Many of the existing STPS were not designed to receive these additional charges. The vast majority of these STPs do not have a system for receiving and pre-treating these residues. However, the need to anticipate these additional loads must be considered, as there is a tendency in places where sewage treatment plants exist (or will exist) to receive septage and faecal sludge to be treated in combination with sewage (CAMPOS et al., 2009).

To avoid the adverse effects of septage discharge on STPS, it is recommended to install septage-receiving facilities before entering the STP, such as grids for the retention of coarse solids, flow equalization tanks, and tanks for removing settleable and floating solids. These septage reception facilities should be inexpensive, simple, requiring very little in operation and maintenance.

The management of septage has been a challenge, due to the complexity of the problem in terms of variability in quality and quantity of these residues and because it involves multiple stakeholders. In any case, decision-making must at least ensure sanitary and environmental protection, preventing the septage to be disposed of in an environmentally inappropriate manner that favours the creation of sites that facilitate the proliferation of vectors and, consequently, the spread of diseases.

According to the Centre for Science and Environment of the Ministry of Urban Development, Government of India (ROHILLA et al., 2017), the most common method used in India for pretreatment of septage is its reception from trucks in a system that uses screening, separation of grit (grit chamber), and tanks or ponds that simultaneously perform sedimentation, thickening of the sludge at the bottom and flotation of scum on the top surface. Alternatively, other kinds of equipment can be found, such as settlers, Imhoff tanks and septic tanks. This technology operates semi-continuously. The liquid effluent flows through the outlet and requires further treatment.

Other methods are also used in India: mechanical dewatering including belt-filter press, frame-filter press, screw press and centrifuge; dewatering and stabilization in geotube bags; stabilization in deep-row entrenchment; stabilization in anaerobic digester; natural dewatering in drying beds; stabilization and dewatering in planted drying beds; lime stabilization; composting and co-composting; stabilization by black soldier fly larvae; pelletizing of dewatered sludge; and stabilization ponds (ROHILLA et al., 2017).

Few studies have been found using diffused air flotation in the treatment or pre-treatment of wastewater and rare are dedicated to septage pretreatment. Borges (2009), working specifically with septage, used microbubble flotation in septage. Gasperi (2012) used the same equipment as Borges' research for the pre-treatment of greasy residues.

In the research by Borges (2009), the septage pre-treatment was carried out in a Pilot Plant for the removal of oils and greases, before being launched 
for co-treatment in the sewage treatment plant. Borges (2009) found removal of oils and greases around $82 \%$. A pH relationship with oils and greases was detected in which whenever the $\mathrm{pH}$ was lower than 6.5 the visual aspect of the sludge indicated the clear presence of oils and greases. Borges (2009) found concentrations of up to $14,531 \mathrm{mg} \mathrm{L}^{-1}$ in the crude septage sample. The flotation unit was operated with rates of surface application of $80,110,140$ and $200 \mathrm{~m}^{3} \mathrm{~m}^{2} \mathrm{~d}^{-1}$. The rate of $110 \mathrm{~m}^{3} \mathrm{~m}^{2} \mathrm{~d}^{-1}$ was the one that produced the greatest removal efficiencies: $91.7 \%$ for suspended solids, $89.3 \%$ for COD, and $81.9 \%$ for oils and greases.

Gasperi (2012) used the pilot unit of Borges' research (BORGES, 2009) to evaluate flotation as an alternative for the pre-treatment of waste from grease traps using a cationic polymer as a chemical additive. Oil and grease removal values superior to $99 \%$ were obtained. When characterizing the residues from grease traps, Gasperi (2012) found a median concentration of oils and greases of $9,653 \mathrm{mg} \mathrm{L}^{-1}$. Tests were performed by Gasperi (2012) using several dosages of polymer associated with three $\mathrm{pH}$ coagulation conditions. The combination that resulted in the best efficiency was $30 \mathrm{mg} \mathrm{L}^{-1}$ of polymer combined to $\mathrm{pH}$ 4.3. Different $\mathrm{A} / \mathrm{S}$ ratios were also tested $(7.5 / 1000,15 / 1000,22 / 1000$ grams of air per grams of solids), the $A / S$ ratio $22 / 1000$ presented the best oil and grease removal efficiencies.

Even though the present research opted for processes of physical treatment of septage (sedimentation and flotation), there are other approaches for the management of FOG in septage. One option that has been widely researched is the collection at the point of generation of used cooking oils, to prevent them from being discharged into the sewage network and to allow them to be more easily transformed into biodiesel or used for soap making. Another approach that is being used in the United States is the anaerobic digestion of FOG, separately or not from septage, allowing the production of biogas to be used as fuel (WILLIAMS et al., 2018).

In this research, the performance of a Pilot Plant for the reception and pre-treatment of waste from septage collection and transport trucks was evaluated, aiming mainly at reducing the concentration of oils and greases from these residues. This septage truck waste comes from cleaning of cesspools, septic tanks, grease taps and other onsite sewage treatment and disposal systems. The objective of this Pilot Plant was to adapt the raw septage to be treated later in a municipal sewage treatment plant, which uses an activated sludge process. This Pilot Plant was composed of a Central Unit that was based on an adaptation of an aerated grit chamber to receive intermittent septage discharges from trucks. The methodology employed included the operation and monitoring of this Pilot Plant. For obtaining results and conclusions, two ways were used to evaluate O\&G removal performance: (1) considering only the Central Unit and (2) globally considering the entire pre-treatment Pilot Plant.

\section{MATERIALS AND METHODS}

\subsection{Pilot Plant Description}

The Pilot Plant used in this research is located next to the existing septage reception installation that operates daily receiving waste discharges from septage trucks. The reception of septage trucks is localized near the entrance of the raw sewage in the Brasilia Sul Sewage Treatment Plant (Brasilia Sul STP).

The Pilot Plant is composed of a grid, an equalization tank, a rotating sieve, a crusher, an air compressor, a 200 litres volumetric tank for storing foam and the pre-treatment Central Unit. Figure 1 shows the configuration of the Pilot Plant (flowchart). Figure 2 presents detailed photographs of the Pilot Plant.

The equalization tank has a rectangular base with approximately $12 \mathrm{~m}^{2}$ of the surface area, a working height of $0.90 \mathrm{~m}$, and the capacity to unload one truck at a time. The equalization tank has three outlets: an outlet through the crusher, located $0.05 \mathrm{~m}$ from the bottom of the tank; an outlet through the rotating sieve, located $0.45 \mathrm{~m}$ from the bottom of the tank; and an outlet for the bottom discharge of the tank. A gate valve follows each exit from the tank. The equalization tank inlet contains a $0.45 \mathrm{~m} \times 0.45 \mathrm{~m}$ box-shaped grid constructed with $3 / 8$ in steel bars spaced $2 \mathrm{~cm}$, for the retention of coarse solids when the waste is discharged from the septage trucks.

The equalization tank was built with the main aim of mixing and homogenizing the waste from the septage trucks that are unloaded before it being carried to the Central Unit. A JWEC-USA model Mini Monster 20000-D100 crusher was installed in one of the outputs of the equalization tank, to crush 
the materials of larger dimensions that were not retained by the grid in the equalization tank and could go to the Central Unit.

Before the entrance of the Central Unit, two junction boxes were built. Junction box No 1 is located just after the equalization tank and junction box No 2 before the entry of the Central Unit. The two boxes are connected by a $4.7 \mathrm{~m}$ long pipe with a diameter of $150 \mathrm{~mm}$. Junction box No 2 and the entrance to the Central Unit are connected by $1 \mathrm{~m}$ long pipe with $100 \mathrm{~mm}$ in diameter.

Figure 1: Configuration of the Pilot Plant for Reception and Pre-treatment of waste from septage trucks.

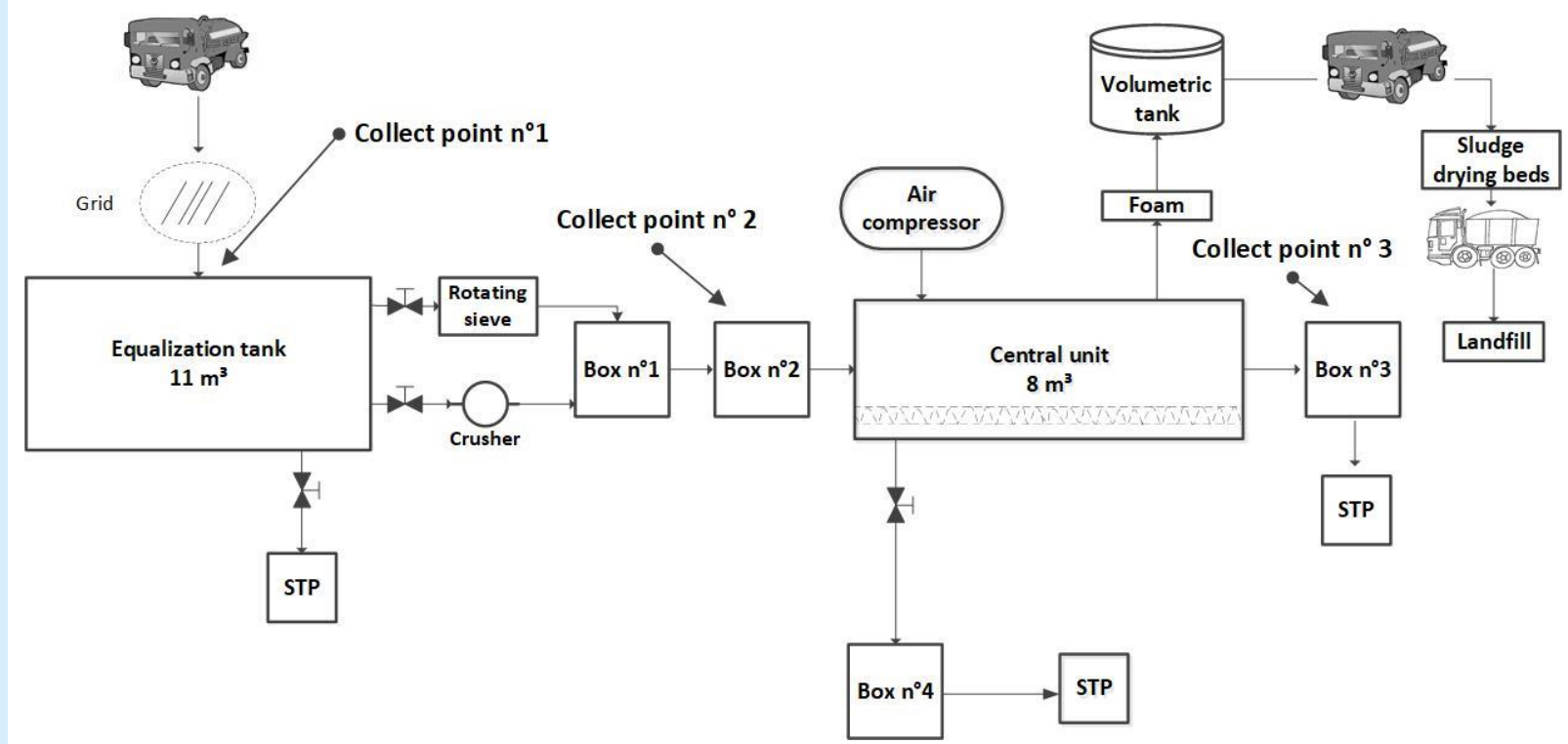

Source: the authors.

Both the pre-treatment Central Unit and the rest of the Pilot Plant were designed and sized for a maximum design flow of $20 \mathrm{~L} \mathrm{~s}^{-1}$, and made of carbon steel and coated internally and externally with tar epoxy.

The Central Unit has two outlets, one for the foam and another for the effluent (liquid fraction) that goes to the STP. The dimensions of the Central Unit are as follows: total length: $7.16 \mathrm{~m}$; compartment length: $7.01 \mathrm{~m}$; total width: $1.706 \mathrm{~m}$; compartment width: $1.406 \mathrm{~m}$. The Central Unit has an internal aeration system, powered by an air compressor, which is independent for each third of the unit (each third is $2.3 \mathrm{~m}$ long). The nozzle diameter of the aeration system holes is $0.7 \mathrm{~mm}$. The air compressor has the capacity for airflow up to $34 \mathrm{~m}^{3} \mathrm{~h}^{-1}$, with a maximum pressure of $170 \mathrm{psi}$; electric motor with $220 / 380 \mathrm{~V}$ voltage and $5 \mathrm{CV}$ power, with 200 litres air reservoir. The aeration system consists of 90 nozzles and has an airflow adjustment from zero to the maximum of the compressor. The Central Unit also has a surface scraper with a rotation of $5 \mathrm{rpm}$, for the removal of foam, in its final upper part. The treadmill for removing the floating material works at a rotation of
$5 \mathrm{rpm}$ and has a width of $1.39 \mathrm{~m}$, with a working length of $1.80 \mathrm{~m}$, and is powered by a reduction motor with a power of $0.33 \mathrm{CV}$, with a reduction of $1: 350$, at $220 / 380 \mathrm{~V}$ voltage and $60 \mathrm{~Hz}$ frequency. For removing the deposited sludge, on bottom discharge, the unit has a helical conveyor (Archimedes' screw) that works at a rotation of 12 rpm and has a helical diameter of $295 \mathrm{~mm}$, with a helical pitch of $200 \mathrm{~mm}$ and is driven by a reducing motor with a power of $1.5 \mathrm{CV}$, at a voltage of 220/380 V, frequency $60 \mathrm{~Hz}$, rotation $1750 \mathrm{rpm}$ (reduction of 1:142.27).

Figure 3 shows some more detailed photographs of the Pilot Plant Central Unit.

\subsection{Modes of operation of the Central Unit}

Four different operating modes were tested in the Central Unit, looking for a minimum configuration allowed for each case with operational feasibility. The operating modes tested were:

- Operation mode No 1: Central Unit without aeration in the initial third, receiving septage from residential and commercial on-site sanitation 
facilities;

- Operation mode No 2: Central Unit with aeration in the initial third, receiving septage from residential and commercial on-site sanitation facilities;

- Operation mode No 3: Central Unit without aeration, receiving greasy residue and septage from residential and commercial on-site sanitation facilities; and

- Operation mode No 4: Central Unit with aeration in the initial third, receiving greasy residue and septage from residential and commercial on-site sanitation facilities.

Figure 2: Detailed photographs of the Pilot Plant: a) front view of the equalization tank; b) entrance of the tank, access to the hoses of the trucks; c) view from inside the tank; d) box-shaped grid at the entrance to the tank.

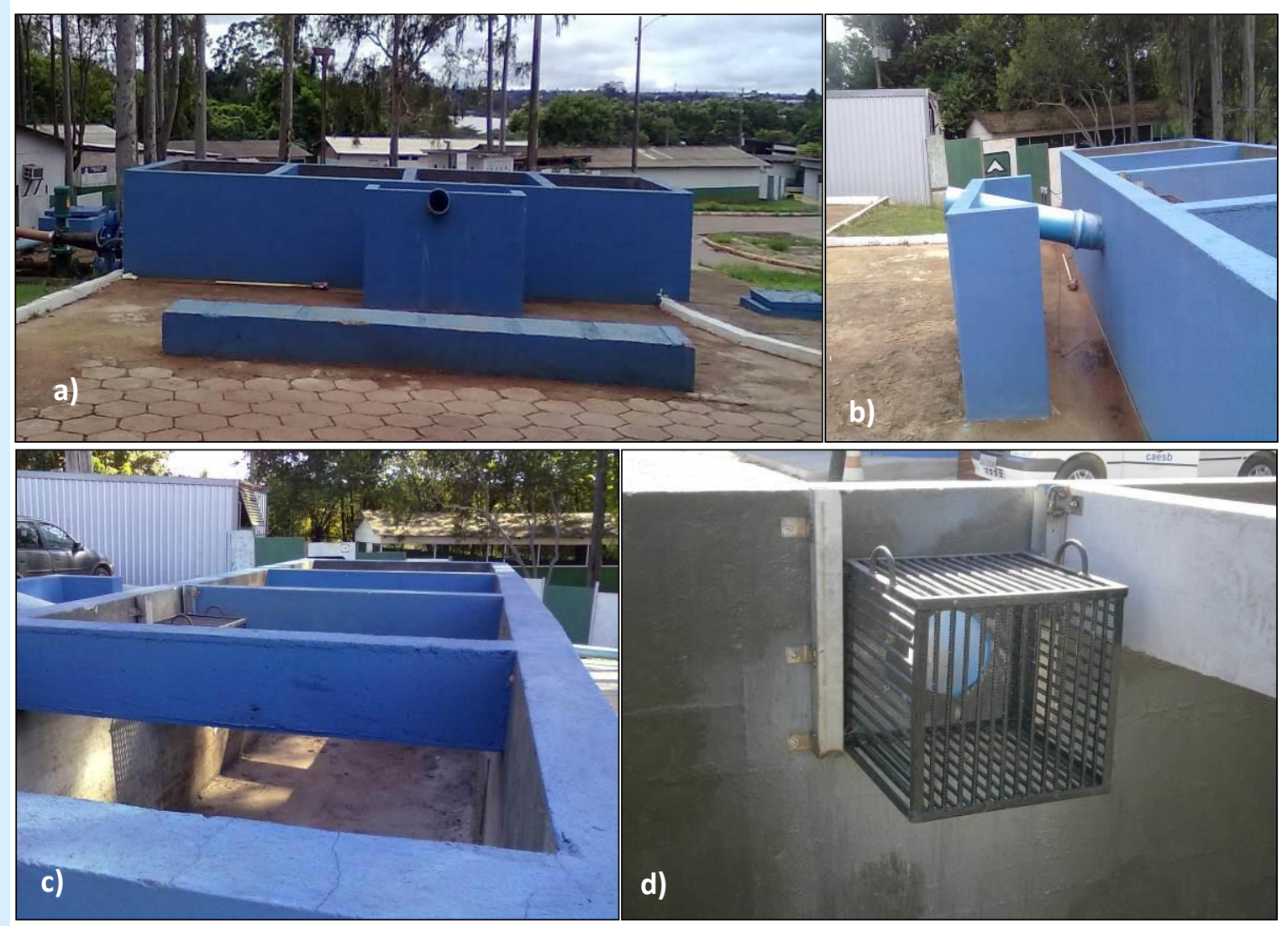

Source: the authors.

Table 1 allows easier visualization of the tested operating modes that have been performed.

All operating modes were tested without the addition of chemicals and operated according to the operational routine for receiving waste from septage trucks at Brasilia Sul STP. For modes of operation No 3 and No 4, attempts were made to mix the greasy residue and septage in volumetric proportions that simulate the reality of receiving septage trucks at the STP. It was not possible to measure the airflow due to the absence of a meter, and because of that, the air valve was opened in 3 turns (maximum opening).

As the effluent outlet from the Central Unit was directly interconnected with the Brasilia Sul STP, precautions were necessary to prevent the dragging of oils and greases to the treatment plant. Priority was given to the reception and pretreatment of septage only. Subsequently, the configuration where grease trap waste was mixed with septage was tested. For reasons of operational safety of the treatment system of Brasilia Sul STP, and for not knowing in advance the behaviour of the Central Unit with residues of grease traps, it was decided not to operate the Pilot Plant with residues with very high contents of oils and greases. Thus the grease trap waste was diluted with septage to minimize the impact on the STP, in case of an incident.

The monitoring of the Pilot Plant was carried out by testing campaigns. Preliminary tests were conducted to determine the stabilization between 
the minimum and maximum operating levels of the equalization tank. After the stabilization, 1-hour collections of the influent samples at the Central Unit were initiated. At the beginning of the time, the first sample of the influent was collected and after 20 minutes (the theoretical detention time) the sample of the Central Unit effluent was collected. This procedure was repeated three times and around 8 litres were collected for the composite sample. The minimum septage volume received was $48 \mathrm{~m}^{3}$ and the maximum $61 \mathrm{~m}^{3}$. The values of the contents of oils and greases presented for both the affluent and the effluent are equivalent to the average of three samples collected in the interval of 20 minutes, during 1 hour of monitoring, except for monitoring campaign No 6, which was carried out in 2 hours in operation mode No 1.

Figure 3: Top view of the helical conveyor and part of the aeration system (on the left) and surface scraper of the Central Unit (on the right) of the Pilot Plant.

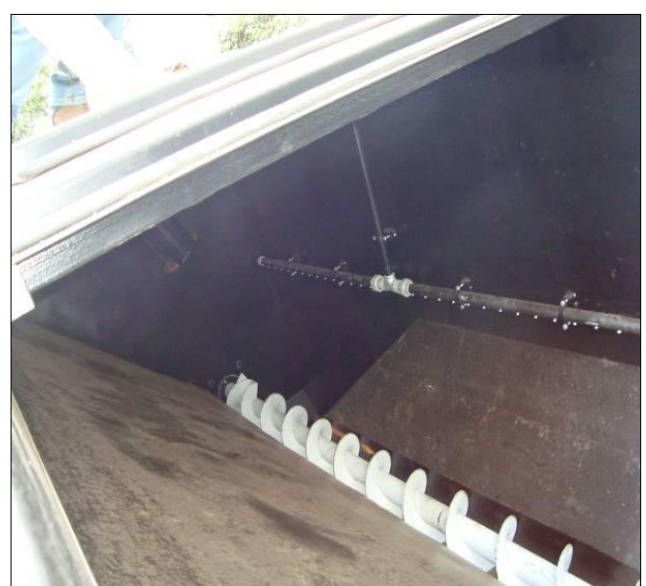

Source: the authors.

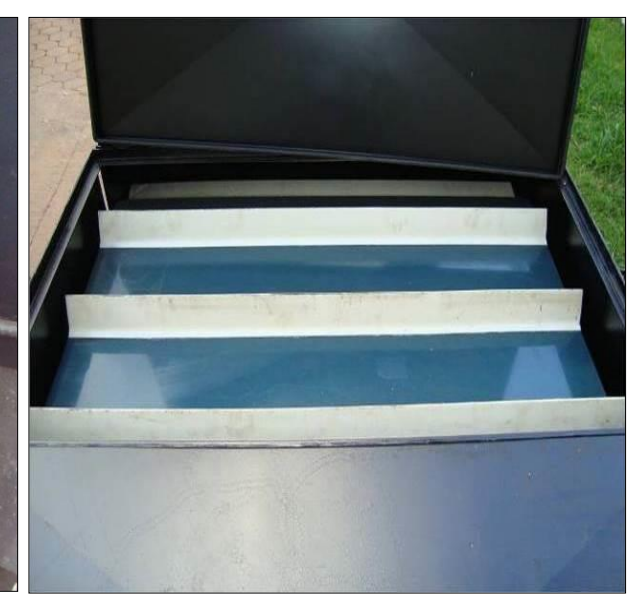

Table 1: Operating modes of the Pilot Plant Central Unit that were tested.

\begin{tabular}{c|c|c|c}
\hline \multirow{2}{*}{$\begin{array}{c}\text { Operation } \\
\text { mode No }\end{array}$} & $\begin{array}{c}\text { Aeration in the initial } \\
\text { third }\end{array}$ & $\begin{array}{c}\mid c \\
\text { Septage from residential and } \\
\text { commercial on-site sanitation } \\
\text { facilities }\end{array}$ & Greasy residue \\
\hline $\mathbf{1}$ & No & Yes & No \\
\hline $\mathbf{2}$ & Yes & Yes & No \\
\hline $\mathbf{3}$ & No & Yes & Yes \\
\hline $\mathbf{4}$ & Yes & Yes & Yes \\
\hline
\end{tabular}

Source: the authors.

It should be noted that, exceptionally, one 2hour campaign was carried out with a sample collection interval every 30 minutes. However, this scheme was not continued due to the logistical difficulty of maintaining its continuity, and it was decided to continue monitoring for $1 \mathrm{~h}$.

Figure 1 also shows the sample collection points for monitoring the Pilot Plant. At point 1, samples were collected at the time when the septage truck was discharging waste into the equalization tank, more precisely after grating, in the jet that the truck's hose produced in the tank. Samples were collected from all trucks that were unloaded during each monitoring campaign and in all operational modes of the Pilot Plant. The sample was composed and collected at the beginning, middle and end of the discharge time for each truck (5 to 15 minutes). At collection point 2, samples were collected from the tributary to the Central Unit, and after the theoretical detention period, samples were collected at collection point 3 , that is, from the Central Unit effluent

At all collection points, after homogenizing the content of the composite sample, a 1 litre aliquot was collected for the analysis of oils and greases and 5 litres for the other examinations, that is, a 
total of 6 litres of truck samples, 18 litres of Central Unit affluent samples ( 6 litres at the beginning of time, 6 litres in 20 minutes and 6 litres in 40 minutes), and 18 litres of Central Unit effluent samples (6 litres in 20 minutes, 6 litres in 40 minutes and 6 litres in 60 minutes).

Information was registered through a waste generator register prepared for the Pilot Plant, containing the following data: origin of the truck waste, frequency of cleaning the on-site facility, collection and disposal date, discharged volume, septage organoleptic characteristics (colour, smell). A field form entitled "Operational Routine Diary" was also used to record occurrences, anomalies, operation and maintenance problems and the number of trucks received in the operation and monitoring of the Pilot Plant.

When unloading the septage truck, the septage was visually inspected for its colour and smell, to determine whether that septage was stabilized or was recent (fresh). This determination was crossed with the information filled in the register of the waste generator. Septage from septic tanks and pits is usually well digested or stabilized by anaerobic process due to the long periods between cleanings or exhaustions. In contrast, septage from systems that are emptied very frequently (from days to few months) tends to be fresh.

Laboratory tests were performed following the procedures recommended in the Standard Methods for the Examination of Water and Wastewater (APHA, 2005). The following tests were carried out for the physical-chemical characterization of the samples collected: total solids, total suspended solids, settleable solids, chemical oxygen demand, and oils and greases. Table 2 shows the test methods used for physicochemical characterization of the septage samples of the trucks that were unloaded at the Brasilia Sul STP.

Table 2: Methods used for the physicochemical characterization of the waste collected from septage trucks in the Brasília Sul STP.

\begin{tabular}{|c|c|c|}
\hline Characteristic & Analysis method & $\begin{array}{l}\text { Method code number in Standard } \\
\text { Methods (APHA, 2005) }\end{array}$ \\
\hline Total Solids - TS & Gravimetric (103-105ㅇ) & $2540 \mathrm{~B}$ \\
\hline $\begin{array}{l}\text { Total Suspended Solids - } \\
\text { TSS }\end{array}$ & Gravimetric (103-105ㄷ) & $2540 \mathrm{D}$ \\
\hline Settleable Solids - SetS & Volumetric (Imhoff cone) & $2540 \mathrm{~F}$ \\
\hline \multirow{2}{*}{$\begin{array}{l}\text { Chemical Oxygen Demand } \\
\text { - COD }\end{array}$} & Closed reflux (for operating modes 1 and 2) & $5220 \mathrm{D}$ \\
\hline & Open reflux (for operating modes 3 and 4) & $5220 \mathrm{~B}$ \\
\hline Oils and Greases - O\&G & Sohxlet & $5520 \mathrm{E}$ \\
\hline
\end{tabular}

Source: the authors.

\subsection{Statistical analysis}

The modes of operation with and without aeration in the initial third of the Central Unit were compared using hypothesis tests, to verify if diffuse aeration was significant for removal of oils and greases from the effluent that followed to be treated together with the sewage. For hypothesis tests, the Mann-Whitney $U$ nonparametric test was used. This test was chosen because it is applied when it is not possible to assume whether the samples were extracted from populations normally distributed and compares groups of independent variables. Besides, the Mann-Whitney $U$ test can be used for groups of small samples, which do not need to have the same size (LEVINE et al., 2008). The hypotheses were tested to a significance level of $5 \%$. Previously, normality tests were performed with the values of oils and greases using the methods of Shapiro-Wilk and KolmogorovSmirnov, which showed that the distribution of these data was not normal. The other results were analysed using descriptive statistics techniques, showing data dispersion and measures of central tendency.

\section{RESULTS AND DISCUSSION}

\subsection{Performance evaluation of the Central Unit receiving only septage (operation modes No 1 and No 2)}

Table 3 shows the removal efficiencies in the Central Unit during operation mode 1 . The efficiency of the Central Unit in the removal of settleable solids varied from $64 \%$ to $92 \%$ when the most stabilized septage volume was equal to or greater than the most recent septage volume. 
When the opposite occurred, there was a removal of settleable solids ranging from $30 \%$ to $50 \%$. This behaviour was expected, since the well-digested septage has a higher settle ability, while fresh septage settles poorly (NARAYANA, 2020).

The same trend was observed for the results of total solids and total suspended solids, but not as expressive as the settleable solids. When the volumetric proportion of more stabilized septage was equal to or greater than the volume of more recent septage, the removal of total and total suspended solids ranged from $24 \%$ to $48 \%$ and from $37 \%$ to $63 \%$, respectively. When the opposite of volumetric proportion occurred, on average, $11 \%$ of total solids and $23 \%$ of total suspended solids removals were observed, as can be seen in Table 3.

Table 3: Removal efficiency obtained in the Central Unit for the evaluated parameters (operation mode No 1).

\begin{tabular}{|c|c|c|c|c|c|c|c|}
\hline \multirow{2}{*}{$\begin{array}{l}\text { Operation } \\
\text { Mode }\end{array}$} & & \multirow{2}{*}{$\begin{array}{c}\text { Monitoring } \\
\text { Campaign }\end{array}$} & \multicolumn{5}{|c|}{ Measured characteristics } \\
\hline & & & $\begin{array}{c}\text { TS } \\
\left(\mathrm{mg} \mathrm{L}^{-1}\right)\end{array}$ & $\begin{array}{c}\text { TSS } \\
\left(\mathrm{mg} \mathrm{L}^{-1}\right)\end{array}$ & $\begin{array}{c}\text { SetS } \\
\left(m L L^{-1}\right)\end{array}$ & $\begin{array}{c}\text { COD } \\
\left(\mathrm{mg} \mathrm{L}^{-1}\right)\end{array}$ & $\begin{array}{c}\text { O\&G } \\
\left(m g L^{-1}\right)\end{array}$ \\
\hline \multirow{18}{*}{$\begin{array}{c}(1) \\
\text { Septage } \\
\text { without } \\
\text { aeration in } \\
\text { Central Unit }\end{array}$} & \multirow{3}{*}{1} & Influent & 1,796 & 1,432 & 15 & - & - \\
\hline & & Effluent & 926 & 527 & 1.2 & - & - \\
\hline & & Removal & $48 \%$ & $63 \%$ & $92 \%$ & - & - \\
\hline & \multirow{3}{*}{2} & Influent & 1,162 & 671 & 3.7 & - & 515 \\
\hline & & Effluent & 1,023 & 533 & 2.3 & - & 353 \\
\hline & & Removal & $12 \%$ & $21 \%$ & $38 \%$ & - & $31 \%$ \\
\hline & \multirow{3}{*}{3} & Influent & 948 & 552 & 6 & - & 1,965 \\
\hline & & Effluent & 840 & 389 & 3 & - & 1,296 \\
\hline & & Removal & $11 \%$ & $30 \%$ & $50 \%$ & - & $34 \%$ \\
\hline & \multirow{3}{*}{4} & Influent & 1,109 & 742 & 9 & - & 1,655 \\
\hline & & Effluent & 797 & 464 & 1 & - & 979 \\
\hline & & Removal & $28 \%$ & $37 \%$ & $89 \%$ & - & $41 \%$ \\
\hline & \multirow{3}{*}{5} & Influent & 1,099 & 384 & 4 & - & 448 \\
\hline & & Effluent & 986 & 316 & 2.8 & - & 345 \\
\hline & & Removal & $10 \%$ & $17 \%$ & $30 \%$ & - & $23 \%$ \\
\hline & \multirow{3}{*}{6} & Influent & 1,459 & 1,024 & 10 & 2,410 & 493 \\
\hline & & Effluent & 1,112 & 591 & 3.6 & 1,866 & 322 \\
\hline & & Removal & $24 \%$ & $42 \%$ & $64 \%$ & $23 \%$ & $35 \%$ \\
\hline
\end{tabular}

Source: the authors.

Table 4 shows the results of the visual inspection made at the time of truck unloading at the Pilot Plant, in each monitoring campaign and during operation mode No 1. These data describe the scenario for each of the six monitoring campaigns in operation mode 1 and help to interpret the results obtained for removal efficiency. In this configuration, the Central Unit performed better in the removal of settleable solids, presenting, in its majority, removal above $50 \%$. Regarding the behaviour in the removal of oils and greases, the Central Unit presented an average removal of $33 \%$, presenting greater removal in monitoring campaign No 4. Based on the concentration of oils and greases, the monitoring campaign No 3 had the highest concentration at the entrance, with $1,955 \mathrm{mg} \mathrm{L}^{-1}$ of $O \& G$, but it was not the one that had the best removal at the end. In the septage, it does not seem to matter the total concentration of oils and greases present, but the way they are present in this concentration.

In operation mode No 2, using aeration in the initial third of the Central Unit, better values were obtained for removing settleable solids (95\%) and oils and greases (46\%). For total solids, the Central Unit showed a maximum removal of $34 \%$ in the third campaign and total suspended solids of $53 \%$ as shown in Table 5.

Table 6 shows the results of the visual inspection made at the time of truck unloading at the Pilot Plant, in each monitoring campaign and during operation mode No 2. These data describe the scenario for each of the three monitoring campaigns in operation mode No 2 and help to 
interpret the results obtained for removal efficiency.

The tests with septage without aeration at the Central Unit had an average removal of $33 \%$ of oils and greases. The tests of septage with aeration had an average removal of $39 \%$ of oils and greases. It was observed that, on average, the removal increase was only $6 \%$ when aeration was used in the initial third of the Central Unit. This result leads to the assumption that, as the aeration system was conceived, there is not much advantage in using aeration receiving only septage. These results also indicate that the oil and grease particles were mostly emulsified and stabilized in the septage. Thus, to obtain substantial increases in the efficiency of removing oils and greases, it would be necessary to design an appropriate flotation system, producing bubbles with a smaller diameter, and to combine with the adoption of auxiliary chemicals for acting as demulsifiers.

Table 4: Description of the scenario for each monitoring campaign in operation mode No 1.

\begin{tabular}{|c|c|c|}
\hline $\begin{array}{l}\text { Monitoring } \\
\text { Campaign }\end{array}$ & Scenario descriptor & Scenario Description \\
\hline \multirow{5}{*}{1} & Total volume received $\left(\mathrm{m}^{3}\right)$ : & 48 \\
\hline & Origin: & residential \\
\hline & Cleaning frequency: & every two days to 6 months \\
\hline & Visual aspect / volume: & $\begin{array}{l}\text { one load of grey septage }\left(19 \mathrm{~m}^{3}\right) \text {, one load of black septage }\left(19 \mathrm{~m}^{3}\right) \\
\text { and one load of brown septage }\left(10 \mathrm{~m}^{3}\right)\end{array}$ \\
\hline & Volumetric proportion: & $1: 1: 0.53$ \\
\hline \multirow{5}{*}{2} & Total volume received $\left(\mathrm{m}^{3}\right)$ : & 61 \\
\hline & Origin: & four residential and one commercial (laundry) \\
\hline & Cleaning frequency: & three times a day to 2 months \\
\hline & Visual aspect / volume: & $\begin{array}{l}\text { two loads of black septage }\left(18 \mathrm{~m}^{3}\right) \text { and three loads of grey septage } \\
\left(43 \mathrm{~m}^{3}\right)\end{array}$ \\
\hline & Volumetric proportion: & $1: 2.4$ \\
\hline \multirow{5}{*}{3} & Total volume received $\left(\mathrm{m}^{3}\right)$ : & 61 \\
\hline & Origin: & residential \\
\hline & Cleaning frequency: & daily to 8 months \\
\hline & Visual aspect / volume: & $\begin{array}{l}\text { two loads of black septage }\left(25 \mathrm{~m}^{3}\right) \text { and two loads of grey septage } \\
\left(36 \mathrm{~m}^{3}\right)\end{array}$ \\
\hline & Volumetric proportion: & $1: 1.44$ \\
\hline \multirow{5}{*}{4} & Total volume received $\left(\mathrm{m}^{3}\right)$ : & 53 \\
\hline & Origin: & two residential and two commercial \\
\hline & Cleaning frequency: & daily to 3 months \\
\hline & Visual aspect / volume: & $\begin{array}{l}\text { two loads of black septage }\left(31 \mathrm{~m}^{3}\right) \text { and two loads of grey septage } \\
\left(22 \mathrm{~m}^{3}\right)\end{array}$ \\
\hline & Volumetric proportion: & $1: 0.71$ \\
\hline \multirow{5}{*}{5} & Total volume received $\left(\mathrm{m}^{3}\right)$ : & 55 \\
\hline & Origin: & $\begin{array}{l}\text { two residential, one commercial (restaurant) and one construction } \\
\text { site }\end{array}$ \\
\hline & Cleaning frequency: & twice a week to 7 months \\
\hline & Visual aspect / volume: & $\begin{array}{l}\text { two black septage loads }\left(17 \mathrm{~m}^{3}\right) \text { and three grey septage loads (38 } \\
\left.\mathrm{m}^{3}\right)\end{array}$ \\
\hline & Volumetric proportion: & $1: 2.24$ \\
\hline \multirow{5}{*}{6} & Total volume received $\left(\mathrm{m}^{3}\right)$ : & 72 \\
\hline & Origin: & residential \\
\hline & Cleaning frequency: & daily to 7 years \\
\hline & Visual aspect / volume: & $\begin{array}{l}\text { three black septage loads }\left(30 \mathrm{~m}^{3}\right) \text {, two grey septage loads }\left(29 \mathrm{~m}^{3}\right) \\
\text { and one brown septage load }\left(13 \mathrm{~m}^{3}\right)\end{array}$ \\
\hline & Volumetric proportion: & $1: 0.97: 0.43$ \\
\hline
\end{tabular}

Source: the authors. 
Table 5: Removal efficiencies obtained in the Central Unit for the evaluated parameters (operation mode No 2).

\begin{tabular}{|c|c|c|c|c|c|c|c|}
\hline \multirow{2}{*}{$\begin{array}{l}\text { Operation } \\
\text { Mode }\end{array}$} & \multirow{2}{*}{\multicolumn{2}{|c|}{$\begin{array}{c}\text { Monitoring } \\
\text { Campaign }\end{array}$}} & \multicolumn{5}{|c|}{ Measured characteristics } \\
\hline & & & $\begin{array}{c}\text { TS } \\
\left(\mathrm{mg} \mathrm{L}^{-1}\right)\end{array}$ & $\begin{array}{c}\text { TSS } \\
\left(\mathrm{mg} \mathrm{L}^{-1}\right)\end{array}$ & $\begin{array}{c}\text { SetS } \\
\left(m L L^{-1}\right)\end{array}$ & $\begin{array}{c}\text { COD } \\
\left(\mathrm{mg} \mathrm{L}^{-1}\right)\end{array}$ & $\begin{array}{c}\text { O\&G } \\
\left(\mathrm{mg} \mathrm{L}^{-1}\right)\end{array}$ \\
\hline \multirow{9}{*}{$\begin{array}{c}(2) \\
\text { Septage } \\
\text { with } \\
\text { aeration in } \\
\text { Central } \\
\text { Unit }\end{array}$} & \multirow{3}{*}{1} & Influent & 1,839 & 910 & 8 & - & 766 \\
\hline & & Effluent & 1,384 & 488 & 0.4 & - & 415 \\
\hline & & Removal & $25 \%$ & $46 \%$ & $95 \%$ & - & $46 \%$ \\
\hline & \multirow{3}{*}{2} & Influent & 1,721 & 991 & 8.2 & 2,335 & 340 \\
\hline & & Effluent & 1,219 & 612 & 3.1 & 1,878 & 223 \\
\hline & & Removal & $29 \%$ & $38 \%$ & $62 \%$ & $20 \%$ & $34 \%$ \\
\hline & \multirow{3}{*}{3} & Influent & 1,144 & 631 & 9 & 1,794 & 452 \\
\hline & & Effluent & 756 & 298 & 1 & 1,457 & 284 \\
\hline & & Removal & $34 \%$ & $53 \%$ & $89 \%$ & $19 \%$ & $37 \%$ \\
\hline
\end{tabular}

Source: the authors.

Table 6: Description of the scenario for each monitoring campaign in operation mode No 2.

\begin{tabular}{|c|c|c|}
\hline $\begin{array}{l}\text { Monitoring } \\
\text { Campaign }\end{array}$ & Scenario descriptor & Scenario Description \\
\hline \multirow{5}{*}{1} & Total volume received $\left(\mathrm{m}^{3}\right)$ : & 28 \\
\hline & Origin: & $\begin{array}{l}\text { two septage loads residential and one septage load from party } \\
\text { house }\end{array}$ \\
\hline & Cleaning frequency: & 20 days to monthly \\
\hline & Visual aspect / volume: & all septage loads of grey colour \\
\hline & Volumetric proportion: & grey septage only \\
\hline \multirow{5}{*}{2} & Total volume received $\left(\mathrm{m}^{3}\right)$ : & 42 \\
\hline & Origin: & $\begin{array}{l}\text { two septage loads residential and commercial (mix), one } \\
\text { septage load residential and one septage load commercial } \\
\text { (laundry) }\end{array}$ \\
\hline & Cleaning frequency: & daily to 3 months \\
\hline & Visual aspect / volume: & $\begin{array}{l}\text { one black septage load }\left(10 \mathrm{~m}^{3}\right) \text { and three grey septage loads } \\
\left(32 \mathrm{~m}^{3}\right)\end{array}$ \\
\hline & Volumetric proportion: & $1: 3.2$ \\
\hline \multirow{5}{*}{3} & Total volume received $\left(\mathrm{m}^{3}\right)$ : & 44 \\
\hline & Origin: & $\begin{array}{l}\text { four residential septage loads and one septage load from } \\
\text { construction site }\end{array}$ \\
\hline & Cleaning frequency: & daily to 2 months \\
\hline & Visual aspect / volume: & $\begin{array}{l}\text { one black septage load }\left(10 \mathrm{~m}^{3}\right) \text { and four grey septage loads (32 } \\
\left.\mathrm{m}^{3}\right)\end{array}$ \\
\hline & Volumetric proportion: & $1: 3.2$ \\
\hline
\end{tabular}

Source: the authors.

Table 7 shows the removal efficiency of the equalization tank in the No 1 and No 2 operating modes (receiving only septage). The equalization tank removed more than $50 \%$ of Settleable Solids, Chemical Oxygen Demand and Oil and Grease. These results show that the equalization tank, even though it was not designed for this purpose, acted as a grease trap and as a grit chamber at the same time.

Table 8 shows the overall efficiency of the Pilot Plant considering all its components. In this case, the equalization tank functioned as a common grit chamber and retained part of the coarse solids that, at times, went through the grid at the time of disposal of the septage at its entrance. In its conception, it was not desired that the equalization tank fulfilled this function; however, it was observed that this occurred.

For the data in Table 8, the samples collected from the trucks were considered as the influent to the Pilot Plant and the effluent of the Central Unit, conveyed to the entrance of the sewage treatment plant, was considered the final effluent.

The Pilot Plant receiving only septage had an 
average oil and grease removal efficiency of $78 \%$. Borges (2009) obtained an average of $82 \%$ removal of $O \& G$ in the dissolved air flotation system from the pilot plant operated, which is not much greater than the removal obtained by the pilot plant in this research.

There was an average COD removal of $63 \%$, which can be considered relatively good for a pretreatment system, but it was possible to verify that the COD concentration in the effluent from the Pilot Plant destined to co-treatment with the sewage is still high $\left(1,767 \mathrm{mg} \mathrm{L}^{-1}\right)$ compared to typical COD values for raw domestic sewage (600 $\left.\mathrm{mg} \mathrm{L}^{-1}\right)$. According to CAESB (2021), the average COD of raw sewage affluent to Brasilia Sul STP is 599.6 $\mathrm{mg} \mathrm{L}^{-1}$ (median of 570.6, maximum and minimum values of 1044.6 and $102.8 \mathrm{mg} \mathrm{L}^{-1}$, respectively). Regarding the series of solids, it is possible to observe a greater removal of settleable solids, reaching an average of $90 \%$, and a lower average removal of total solids, of $64 \%$. The Pilot Plant showed average removals above $50 \%$ for the analysed characteristics and, mainly, for the reduction of the concentration of oils and greases.

Table 7: Average removal efficiency of the equalization tank for the evaluated parameters, receiving only septage (operation modes No 1 and No 2).

\begin{tabular}{|c|c|c|c|c|c|}
\hline \multirow{2}{*}{ Examined waste } & \multicolumn{5}{|c|}{ Measured characteristics } \\
\cline { 2 - 6 } & $\begin{array}{c}\text { TS } \\
\left(\mathbf{m g ~ L}^{-1}\right)\end{array}$ & $\begin{array}{c}\text { TSS } \\
\left(\mathrm{mg} \mathrm{L}^{-1}\right)\end{array}$ & $\begin{array}{c}\text { SetS } \\
\left(\mathrm{mL} \mathrm{L}^{-1}\right)\end{array}$ & $\begin{array}{c}\text { COD } \\
\left(\mathbf{m g ~ L}^{-1}\right)\end{array}$ & $\begin{array}{c}\text { O\&G } \\
\left(\mathbf{m g ~ L}^{-1}\right)\end{array}$ \\
\hline $\begin{array}{c}\text { Influent } \\
\text { (coming from trucks) }\end{array}$ & 2,665 & 1,862 & 20 & 4,499 & 1,750 \\
\hline $\begin{array}{c}\text { Effluent } \\
\text { (Central Unit input) }\end{array}$ & 1,364 & 815 & 8 & 1,750 & 829 \\
\hline Removal & $\mathbf{4 9 \%}$ & $\mathbf{5 6 \%}$ & $\mathbf{5 9 \%}$ & $\mathbf{5 2 \%}$ & $\mathbf{5 3 \%}$ \\
\hline
\end{tabular}

Source: the authors.

Table 8: Average removal efficiency of the Pilot Plant for the evaluated parameters, receiving only septage (operation modes No 1 and No 2).

\begin{tabular}{c|c|c|c|c|c}
\hline \multirow{2}{*}{ Examined waste } & \multicolumn{5}{|c}{ Measured characteristics } \\
\cline { 2 - 6 } & $\begin{array}{c}\text { TS } \\
\left(\mathbf{m g ~ L}^{-1}\right)\end{array}$ & $\begin{array}{c}\text { TSS } \\
\left(\mathbf{m g ~ L}^{-1}\right)\end{array}$ & $\begin{array}{c}\text { SetS } \\
\left(\mathbf{m L ~ L}^{-1}\right)\end{array}$ & $\begin{array}{c}\text { COD } \\
\left(\mathbf{m g ~ L}^{-1}\right)\end{array}$ & $\begin{array}{c}\text { O\&G } \\
\left(\mathbf{m g ~ L}^{-1}\right)\end{array}$ \\
\hline $\begin{array}{c}\text { Influent } \\
\text { (coming from trucks) }\end{array}$ & 2,834 & 1,983 & 21 & 4,741 & 1,802 \\
\hline $\begin{array}{c}\text { Effluent } \\
\text { (Central Unit output) }\end{array}$ & 1,033 & 468 & 2 & 1,767 & 483 \\
\hline Removal & $\mathbf{6 4 \%}$ & $\mathbf{7 6 \%}$ & $\mathbf{9 0 \%}$ & $\mathbf{6 3 \%}$ & $\mathbf{7 8 \%}$ \\
\hline
\end{tabular}

Source: the authors.

\subsection{Performance evaluation of the Central Unit receiving greasy residue and septage (operating modes No 3 and No 4)}

In operation modes No 3 and No 4, the Pilot Plant received mixtures of greasy residues and septage.

Table 9 shows the removal efficiencies of the Central Unit in operation mode No 3 (without aeration in the initial third of the Central Unit and with greasy residues) and the scenarios for each monitoring campaign. Table 10 contains the description of the scenario for each monitoring campaign in the No 3 operation mode.

In the same way as performed in operation mode No 2, operation mode No 4 had aeration in the initial third of the Central Unit. Table 11 presents the efficiency of removing the characteristics studied in operation mode No 4 and the scenarios for each monitoring campaign. Table 12 shows the results measured in situ that characterize the scenario of each monitoring campaign in the No 4 operation mode.

Removals of settleable solids were around $60 \%$, with a lower removal of $29 \%$ in the first monitoring campaign. It is possible to observe 
again the influence of recent (fresh) septage and more stabilized septage, because when the latter was present, even in a smaller volumetric proportion compared to the greasy residue, the system showed $78 \%$ efficiency, but when the septage was recent (fresh), that was the majority in the first monitoring campaign, the efficiency was only $29 \%$. The same happened with removal of suspended solids, which was $25 \%$ in that same campaign. Among the series of solids, the total solids content was still the one that showed the least removal within the Central Unit.

Table 9: Efficiency of removal of the Central Unit for the evaluated parameters (operation mode No 3).

\begin{tabular}{|c|c|c|c|c|c|c|c|}
\hline \multirow{2}{*}{$\begin{array}{l}\text { Operation } \\
\text { Mode }\end{array}$} & \multirow{2}{*}{\multicolumn{2}{|c|}{$\begin{array}{c}\text { Monitoring } \\
\text { Campaign }\end{array}$}} & \multicolumn{5}{|c|}{ Measured characteristics } \\
\hline & & & $\begin{array}{c}\text { TS } \\
\left(\mathrm{mg} \mathrm{L}^{-1}\right)\end{array}$ & $\begin{array}{c}\text { TSS } \\
\left(\mathrm{mg} \mathrm{L}^{-1}\right)\end{array}$ & $\begin{array}{c}\text { SetS } \\
\left(m L L^{-1}\right)\end{array}$ & $\begin{array}{c}\text { COD } \\
\left(\mathrm{mg} \mathrm{L}^{-1}\right)\end{array}$ & $\begin{array}{c}\text { O\&G } \\
\left(\mathrm{mg} \mathrm{L}^{-1}\right)\end{array}$ \\
\hline \multirow{9}{*}{$\begin{array}{l}(3) \\
\text { Greasy } \\
\text { residue and } \\
\text { septage } \\
\text { without } \\
\text { aeration in } \\
\text { Central Unit }\end{array}$} & \multirow{3}{*}{1} & Influent & 2,707 & 1,743 & 24 & 6,373 & 569 \\
\hline & & Effluent & 2,381 & 1,307 & 17 & 3,878 & 385 \\
\hline & & Removal & $12 \%$ & $25 \%$ & $29 \%$ & $39 \%$ & $32 \%$ \\
\hline & \multirow{3}{*}{2} & Influent & 4,137 & 2,539 & 33 & 19,600 & 707 \\
\hline & & Effluent & 2,676 & 1,099 & 7.2 & 13,393 & 386 \\
\hline & & Removal & $35 \%$ & $57 \%$ & $78 \%$ & $32 \%$ & $45 \%$ \\
\hline & \multirow{3}{*}{3} & Influent & 6,034 & 3,805 & 33 & 10,453 & 1,163 \\
\hline & & Effluent & 2,721 & 1,537 & 9.8 & 6,207 & 596 \\
\hline & & Removal & $55 \%$ & $60 \%$ & $70 \%$ & $41 \%$ & $49 \%$ \\
\hline
\end{tabular}

Source: the authors.

Table 10: Description of the scenario for each monitoring campaign in operation mode No 3.

\begin{tabular}{|c|c|c|}
\hline $\begin{array}{l}\text { Monitoring } \\
\text { Campaign }\end{array}$ & Scenario descriptor & Scenario Description \\
\hline \multirow{5}{*}{1} & Total volume received $\left(\mathrm{m}^{3}\right)$ : & 42 \\
\hline & Origin: & $\begin{array}{l}18 \mathrm{~m}^{3} \text { of greasy residue }\left(5 \mathrm{~m}^{3} \text { : residential; } 13 \mathrm{~m}^{3}: \text { commercial- }\right. \\
\text { restaurant) and } 24 \mathrm{~m}^{3} \text { of septage (14 } \mathrm{m}^{3} \text { : residential and } \\
\text { commercial; } 10 \mathrm{~m}^{3} \text { : construction site) }\end{array}$ \\
\hline & Cleaning frequency: & $\begin{array}{l}\text { greasy residue (weekly and } 1 \text { did not know how to inform), fresh } \\
\text { septage (biweekly to monthly) }\end{array}$ \\
\hline & Visual aspect / volume: & greasy residue (all grey) and septage (all grey) \\
\hline & Volumetric proportion: & $1: 1.5$ \\
\hline \multirow{5}{*}{2} & Total volume received $\left(\mathrm{m}^{3}\right)$ : & 34 \\
\hline & Origin: & $\begin{array}{l}26 \mathrm{~m}^{3} \text { of greasy residue }\left(13 \mathrm{~m}^{3}: \text { club; } 13 \mathrm{~m}^{3} \text { : commercial- }\right. \\
\text { restaurant) and } 8 \mathrm{~m}^{3} \text { of residential septage }\end{array}$ \\
\hline & Cleaning frequency: & greasy residue (weekly to monthly), septage (half-yearly) \\
\hline & Visual aspect / volume: & $\begin{array}{l}\text { greasy residue (13 } \mathrm{m}^{3} \text { grey and } 13 \mathrm{~m}^{3} \text { brown) and stabilized } \\
\text { septage (black) }\end{array}$ \\
\hline & Volumetric proportion: & $1: 0.31$ \\
\hline \multirow{5}{*}{3} & Total volume received $\left(\mathrm{m}^{3}\right)$ : & 66 \\
\hline & Origin: & $\begin{array}{l}39 \mathrm{~m}^{3} \text { of greasy residue }\left(20 \mathrm{~m}^{3}: \text { commercial - restaurant; } 13 \mathrm{~m}^{3} \text { : }\right. \\
\text { commercial; } 6 \mathrm{~m}^{3} \text { : public agency), } 13 \mathrm{~m}^{3} \text { of residential septage, } \\
6 \mathrm{~m}^{3} \text { of commercial septage and } 8 \mathrm{~m}^{3} \text { of septage from a hospital }\end{array}$ \\
\hline & Cleaning frequency: & $\begin{array}{l}\text { greasy residue ( } 3 \text { times a week, monthly), fresh septage (weekly } \\
\text { to monthly) }\end{array}$ \\
\hline & Visual aspect / volume: & $\begin{array}{l}\text { greasy residue ( } 29 \mathrm{~m}^{3} \text { brown and } 10 \mathrm{~m}^{3} \text { grey) and septage } \\
\text { (grey) }\end{array}$ \\
\hline & Volumetric proportion: & $1: 0.69$ \\
\hline
\end{tabular}

Source: the authors. 
Table 11: Efficiency of removal of the Central Unit for the evaluated parameters (operation mode No 4).

\begin{tabular}{|c|c|c|c|c|c|c|c|}
\hline \multirow{2}{*}{$\begin{array}{l}\text { Operation } \\
\text { Mode }\end{array}$} & \multirow{2}{*}{\multicolumn{2}{|c|}{$\begin{array}{l}\text { Monitoring } \\
\text { Campaign }\end{array}$}} & \multicolumn{5}{|c|}{ Measured characteristics } \\
\hline & & & $\begin{array}{c}\text { TS } \\
\left(\mathrm{mg} \mathrm{L}^{-1}\right)\end{array}$ & $\begin{array}{c}\text { TSS } \\
\left(\mathrm{mg} \mathrm{L}^{-1}\right)\end{array}$ & $\begin{array}{c}\text { SetS }(\mathrm{mL} \\
\left.\mathrm{L}^{-1}\right)\end{array}$ & $\begin{array}{c}\text { COD } \\
\left(\mathrm{mg} \mathrm{L}^{-1}\right)\end{array}$ & $\begin{array}{c}\text { O\&G } \\
\left(\mathrm{mg} \mathrm{L}^{-1}\right)\end{array}$ \\
\hline \multirow{9}{*}{$\begin{array}{c}(4) \\
\text { Greasy } \\
\text { residue and } \\
\text { Septage } \\
\text { with aeration } \\
\text { in Central } \\
\text { Unit }\end{array}$} & \multirow{3}{*}{1} & Influent & 1,996 & 818 & 10,2 & 17,967 & 805 \\
\hline & & Effluent & 1,785 & 645 & 5.6 & 11,760 & 223 \\
\hline & & Removal & $11 \%$ & $21 \%$ & $45 \%$ & $35 \%$ & $72 \%$ \\
\hline & \multirow{3}{*}{2} & Influent & 4,984 & 3,501 & 44 & 23,613 & 2,566 \\
\hline & & Effluent & 1,760 & 800 & 6.6 & 5,827 & 376 \\
\hline & & Removal & $65 \%$ & $77 \%$ & $85 \%$ & $75 \%$ & $85 \%$ \\
\hline & \multirow{3}{*}{3} & Influent & 4,975 & 2,448 & 39,8 & 6,860 & 1,738 \\
\hline & & Effluent & 1,137 & 604 & 3.3 & 3,920 & 587 \\
\hline & & Removal & $77 \%$ & $75 \%$ & $92 \%$ & $43 \%$ & $66 \%$ \\
\hline
\end{tabular}

Source: the authors.

Table 12: Description of the scenario for each monitoring campaign in operation mode No 4.

\begin{tabular}{|c|c|c|}
\hline $\begin{array}{l}\text { Monitoring } \\
\text { Campaign }\end{array}$ & Scenario descriptor & Scenario Description \\
\hline \multirow{5}{*}{1} & Total volume received $\left(\mathrm{m}^{3}\right)$ : & 40 \\
\hline & Origin: & $\begin{array}{l}13 \mathrm{~m}^{3} \text { of greasy residue (restaurant) and } 27 \mathrm{~m}^{3} \text { of residential } \\
\text { septage }\end{array}$ \\
\hline & Cleaning frequency: & $\begin{array}{l}\text { greasy residue (weekly), septage (twice a week every two } \\
\text { months) }\end{array}$ \\
\hline & Visual aspect / volume: & greasy residue (grey) and septage $\left(20 \mathrm{~m}^{3}\right.$ grey and $7 \mathrm{~m}^{3}$ brown) \\
\hline & Volumetric proportion: & $1: 2.1$ \\
\hline \multirow{5}{*}{2} & Total volume received $\left(\mathrm{m}^{3}\right)$ : & 45 \\
\hline & Origin: & $\begin{array}{l}33 \mathrm{~m}^{3} \text { of greasy residue (restaurants) and } 12 \mathrm{~m}^{3} \text { of commercial } \\
\text { septage }\end{array}$ \\
\hline & Cleaning frequency: & $\begin{array}{l}\text { greasy residue (weekly; one the operator was unable to inform), } \\
\text { septage (operator was unable to inform) }\end{array}$ \\
\hline & Visual aspect / volume: & $\begin{array}{l}\text { greasy residue }\left(20 \mathrm{~m}^{3} \text { grey and } 13 \mathrm{~m}^{3} \text { brown) and septage }\right. \\
\text { (grey) }\end{array}$ \\
\hline & Volumetric proportion: & $1: 0.36$ \\
\hline \multirow{5}{*}{3} & Total volume received $\left(\mathrm{m}^{3}\right)$ : & 48 \\
\hline & Origin: & $\begin{array}{l}11 \mathrm{~m}^{3} \text { of residential greasy residue, } 15 \mathrm{~m}^{3} \text { of residential septage, } \\
10 \mathrm{~m}^{3} \text { of commercial septage (laundry) and } 12 \mathrm{~m}^{3} \text { of } \\
\text { construction site septage }\end{array}$ \\
\hline & Cleaning frequency: & greasy residue (not obtained), septage (daily to monthly) \\
\hline & Visual aspect / volume: & greasy residue (grey) and septage (grey) \\
\hline & Volumetric proportion: & $1: 3.36$ \\
\hline
\end{tabular}

Source: the authors.

The removal at the Central Unit of oils and greases, in operation mode No 3, was around $42 \%$, presenting a removal close to $50 \%$ in the third monitoring campaign. In operation mode No 4 , the efficiency of removing oils and greases was between $66 \%$ and $85 \%$. These results suggest that the more the residues were greasy, the more efficient the removal of oils and greases became. Total solids also increased from campaign 1 to 3 . It is possible that the fat has adhered to the solids, favouring their removal.

In relation to operation mode No 4 , in the first and third monitoring campaigns, it was possible to observe a lower value of greasy residues discharged in the Pilot Plant. However, when using aeration, even without knowing exactly the airflow used, it was possible to observe that the aeration promoted an increase in the removal of oils and greases (when comparing to campaigns without aeration). If compared to operating mode 3 , there 
was an increase of $32 \%$ in the removal of oils and greases when aeration was used in the initial third of the Central Unit. The removal of oils and greases in this operational mode was around $74 \%$, with $85 \%$ removal of oils and greases when the presence of fats in the system was greater than that of septage.

In operation modes 3 and 4 , the concentration of oils and greases in the effluent of the Pilot Plant that was released to be co-treated at Brasilia Sul STP was $426 \mathrm{mg} \mathrm{L}^{-1}$ on average

Table 13 presents the results of average removals from the equalizer tank when receiving mixtures of septage and fatty residues (operating modes No 3 and No 4). In the same way as with the No 1 and No 2 operating modes, the equalization tank worked as a grit chamber and grease trap in the No 3 and No 4 operating modes.

The characterization of the grease traps residues made by Gasperi (2012) found a median concentration of oils and greases of $9,653 \mathrm{mg} \mathrm{L}^{-1}$. This suggests that if only greasy residues were analysed in the present study, the values found in the characterization of the raw samples in modes 3 and 4 would certainly be higher.

Gasperi (2012) obtained 99\% average O\&G removal in the dissolved air flotation system with the dosage of the polymer, which demonstrates that it would be necessary to use chemicals to increase the efficiency of the Pilot Plant and decrease the concentration of O\&G in its effluent.

Table 14 shows the overall efficiency of the Pilot Plant. The average removal efficiencies were calculated for modes of operation No 3 and No 4 .

The average removal values of oils and greases in the Pilot Plant were very close for the operational modes No 3 and No 4 , of $94 \%$ and $96 \%$, respectively.

In general, the Pilot Plant behaved better with greasy residues, mainly due to the presence of free fat. It is assumed that a large part of this free fat was retained in the equalization tank and that the equalization tank attenuated the loads that were released to the Central Unit. However, it can be observed that, with higher concentrations of oils and greases, the Central Unit tended to increase its removal capacity.

The average concentration of oils and greases that followed for co-treatment with sewage at Brasilia Sul STP after going through the pretreatment at the Central Unit of the Pilot Plant in the modes of operation receiving only septage was $527 \mathrm{mg} \mathrm{L}^{-1}$. In the modes of operation that receive septage and waste from grease traps, the average concentration of oils and greases was $426 \mathrm{mg} \mathrm{L}^{-1}$. These values are even higher than the concentration of oils and greases in sewage (around $150 \mathrm{mg} \mathrm{L}^{-1}$ ). Regarding the maximum oil and grease content accepted by the local legislation for sewage to be treated in STP in the Federal District of Brazil, the O\&G concentrations are greater than the expected average value and less than the maximum expected value, of $300 \mathrm{mg}$ $\mathrm{L}^{-1}$ and $540 \mathrm{mg} \mathrm{L}^{-1}$, respectively (DISTRITO FEDERAL, 1997). According to CAESB (2021), the average $O \& G$ in the affluent raw sewage at Brasilia Sul STP is $29.2 \mathrm{mg} \mathrm{L}^{-1}$ (median of 19.6, maximum and minimum values of 52.4 and $4.3 \mathrm{mg} \mathrm{L}^{-1}$, respectively). Despite this, the volume of waste from septage trucks is very small compared to the raw sewage flow being received by Brasilia Sul STP, which is higher than $1,000 \mathrm{~L} \mathrm{~s}^{-1}$, and no impact has been registered or is expected if this waste undergoes this type of pre-treatment.

It is worth mentioning that in none of the modes of operation any chemicals were used to assist in the pre-treatment process, to show the technical and economic viability of the process, in addition to its operational simplicity. The forms of oils that could be removed in this configuration were those that were in their free form or adhered to the solids, as described in the literature.

Table 13: Average removal efficiency of the equalization tank for the evaluated parameters when receiving mixtures of septage and greasy waste.

\begin{tabular}{|c|l|l|l|l|l|}
\hline \multirow{2}{*}{ Examined waste } & \multicolumn{5}{|c|}{ Measured characteristics } \\
\cline { 2 - 6 } & \multicolumn{1}{|c|}{$\begin{array}{c}\text { TS } \\
\left(\mathrm{mg} \mathrm{L}^{-1}\right)\end{array}$} & $\begin{array}{c}\text { TSS } \\
\left(\mathrm{mg} \mathrm{L}^{-1}\right)\end{array}$ & $\begin{array}{c}\text { SetS } \\
\left(\mathrm{mL} \mathrm{L}^{-1}\right)\end{array}$ & $\begin{array}{c}\text { COD } \\
\left(\mathrm{mg} \mathrm{L}^{-1}\right)\end{array}$ & $\begin{array}{c}\text { O\&G } \\
\left(\mathrm{mg} \mathrm{L}^{-1}\right)\end{array}$ \\
\hline $\begin{array}{c}\text { Influent } \\
\text { (trucks) }\end{array}$ & 10,630 & 7,017 & 61 & 25,088 & 9,024 \\
\hline $\begin{array}{c}\text { Effluent } \\
\text { (Central Unit input) }\end{array}$ & 4,139 & 2,476 & 31 & 14,144 & 1,258 \\
\hline Removal & $\mathbf{6 1 \%}$ & $\mathbf{6 5 \%}$ & $\mathbf{4 9 \%}$ & $\mathbf{4 4 \%}$ & $\mathbf{8 6 \%}$ \\
\hline
\end{tabular}

Source: the authors. 
Table 14: Average removal efficiency of the Pilot Plant for the evaluated parameters, considering the No 3 and No 4 operating modes of the Central Unit receiving septage and greasy residues.

\begin{tabular}{|c|c|c|c|c|c|c|}
\hline \multirow{2}{*}{\multicolumn{2}{|c|}{ Central Unit Operation Mode }} & \multicolumn{5}{|c|}{ Measured Characteristics } \\
\hline & & \multirow{2}{*}{$\begin{array}{c}\begin{array}{c}\text { TS } \\
\left(\mathrm{mg} \mathrm{L}^{-1}\right)\end{array} \\
9,165\end{array}$} & \multirow{2}{*}{$\begin{array}{c}\begin{array}{c}\text { TSS } \\
\left(\mathrm{mg} \mathrm{L}^{-1}\right)\end{array} \\
7,486\end{array}$} & \multirow{2}{*}{$\begin{array}{c}\begin{array}{c}\text { SetS } \\
\left(\mathrm{mL} \mathrm{L}^{-1}\right)\end{array} \\
70\end{array}$} & \multirow{2}{*}{$\begin{array}{c}\begin{array}{c}\text { COD } \\
\left(\mathrm{mg} \mathrm{L}^{-1}\right)\end{array} \\
23,670\end{array}$} & \multirow{2}{*}{$\begin{array}{c}\begin{array}{c}\text { O\&G } \\
\left(\mathrm{mg} \mathrm{L}^{-1}\right)\end{array} \\
8,216\end{array}$} \\
\hline \multirow{3}{*}{$\begin{array}{c}\text { (3) } \\
\text { Central Unit } \\
\text { without } \\
\text { aeration }\end{array}$} & $\begin{array}{l}\text { Influent } \\
\text { (Trucks) }\end{array}$ & & & & & \\
\hline & $\begin{array}{c}\text { Effluent } \\
\text { (Central Unit } \\
\text { output) }\end{array}$ & 2,593 & 1,314 & 11 & 17,640 & 456 \\
\hline & Removal & $72 \%$ & $82 \%$ & $84 \%$ & $67 \%$ & $94 \%$ \\
\hline \multirow{3}{*}{$\begin{array}{c}(4) \\
\text { Central Unit } \\
\text { with } \\
\text { aeration }\end{array}$} & $\begin{array}{l}\text { Influent } \\
\text { (Trucks) }\end{array}$ & 12,095 & 6,548 & 51 & 26,507 & 9,833 \\
\hline & $\begin{array}{c}\text { Effluent } \\
\text { (Central Unit } \\
\text { output) }\end{array}$ & 1,561 & 683 & 5 & 7,169 & 395 \\
\hline & Removal & $87 \%$ & $90 \%$ & $90 \%$ & $73 \%$ & $96 \%$ \\
\hline
\end{tabular}

Source: the authors.

\subsection{Comparison between the operation modes of the Central Unit}

It was verified whether the concentrations of oils and greases in the effluent of the Pilot Plant that was discharged to Brasilia Sul STP showed or not statistically significant differences when using aeration in the initial third of the Central Unit.

When the Mann-Whitney $U$ nonparametric hypothesis test was applied, with a significance level of $p=0.05$, the differences were not significant when aeration was used or not in the initial third of the Central Unit, for operating modes No 1 and No 2 (with the system being fed only with septage). The same result was obtained for operating modes No 3 and No 4, in which the Pilot Plant received a mixture of septage and greasy residues.

In part, these results can be justified by the fact that the oils and greases are mostly emulsified in the septage, due to the presence of surfactants from detergents, and they may be in the form of micro droplets with a diameter less than $50 \mu \mathrm{m}$, which hinders their separation by gravitational processes. If it were desired to remove the emulsified oils, it would be necessary to use the flotation associated with the addition of chemicals (SANTANDER, RODRIGUES \& RUBIO, 2010).

\section{CONCLUSIONS}

The reduction of oils and greases by the Pilot Plant was considerable and acceptable when comparing the initial concentration of the crude waste with its concentration after pre-treatment. With the pre-treatment done by the Pilot Plant, no impact on STP due to oils and greases has been verified or can be expected.

The tests with only septage, and without aeration at the Central Unit, showed an average removal of $33 \%$ of oils and greases. With aeration in the initial third, these tests showed an average removal of $39 \%$ of oils and greases. When receiving greasy residue and septage, working without aeration, the average removal of oils and greases was around $42 \%$, but with aeration in the initial third of the Central Unit, the average removal of oils and greases was $74 \%$. However, the statistical test used under the specified conditions did not demonstrate a significant difference between the efficiency of the Central Unit with and without aeration.

As the results of the tests with and without aeration were very close, under the conditions of these tests at the Pilot Plant, the benefits of operational simplicity and costs of working without aeration uphold the decision of not to include aeration in the process.

To obtain substantial increases in the efficiency of removing oils and greases, it would be necessary to use another flotation system more appropriate to the case, such as dissolved air flotation, and combine this with the adoption of auxiliary chemicals. This would represent an increase in costs that are probably not offset by benefits.

The efficiency of removing settleable solids is greatly influenced by the degree of septage 
stability, which is proportional to the time between two cleanings of the on-site sewage treatment facilities. The greater the degree of septage digestion the greater the removal of settleable solids. Thus, the efficiency of removing settleable solids ranged from $29 \%$ (for fresh septage) to $92 \%$ (for more stabilized septage).

The Pilot Plant removed an average of $72 \%$ of oils and greases and $90 \%$ of settleable solids when receiving only septage from trucks (operating modes No 1 and No 2). Upon receiving septage mixed with greasy residues (modes of operation No 3 and No 4), it removed an average of $96 \%$ of the oils and greases and $90 \%$ of the settleable solids from the effluent that after went to the sewage treatment plant.

The composite samples collected from the trucks in each monitoring campaign and the input samples from the Central Unit showed that part of the total settleable and suspended solids, O\&G and COD was retained in the equalization tank. The equalization tank operated as a grit chamber and as an oil-water separator at the Pilot Plant, attenuating the loads that went to the Central Unit. In the presence of grease trap residues, the equalization tank retained greater amounts of oils and greases, especially oils and greases in their free form.

The equalization tank alone was responsible for a reasonable removal of COD, O\&G, and Solids. This fact proves that the septage pretreatment and conditioning to be introduced in the sewage treatment system can be simple, low cost, and undemanding in operation and maintenance.

The Pilot Plant treating only septage reached an average removal efficiency of $63 \%$ of COD and $73 \%$ of O\&G. When the Pilot Plant received mixtures of septage and greasy waste, these efficiencies increased to $78 \%$ and $96 \%$ of COD and $\mathrm{O} \& \mathrm{G}$, respectively. These results demonstrate that the increase in the concentration of O\&G favours its process of separation, although the research has not determined the limit for the introduction of greasy residues.

As a practical conclusion, this research found that a simple and low-cost installation, without aeration and addition of chemicals, might condition the septage to be treated in conjunction with municipal wastewater.

\section{REFERENCES}

AL-SA'ED, R. M. Y.; HITHNAWI, T. M. Domestic septage characteristics and cotreatment impacts on Albireh
Wastewater Treatment Plant Efficiency. Dirasat, Engineering Sciences, V. 33, No. 2, pp. 187-197. 2006.

APHA Standard Methods for the Examination of Water and Wastewater. $21^{\text {st }}$ edition. Washington, DC, USA: APHA - American Public Health Association, AWWA - American Water Works Association, WEF Water Environment Federation. 2005.

ANDREOLI, C. V. (Coord.) Lodo de fossa e tanque séptico: caracterização, tecnologias de tratamento, gerenciamento e destino final (Septage: characterization, treatment technologies, management and final destination). Curitiba, PR, Brazil: ABES. Programa de pesquisa em saneamento básico PROSAB. 383p. Available at: https://www.finep.gov.br/images/apoio-e-

financiamento/historico-de-

programas/prosab/prosab5 tema 6.pdf. 2009.

BORGES, N. B. Caracterização e pré-tratamento de lodos de fossas e tanques sépticos. Dissertação de Mestrado. (Characterization and pre-treatment of septage. Masters dissertation). São Carlos, SP, Brazil: Escola de Engenharia de São Carlos da Universidade de São Paulo - EESC-USP. 150p. Available at: https://www.teses.usp.br/teses/disponiveis/18/18138/td e-30032010-151857/publico/nayaraborges.pdf . 2009.

CAESB Base de dados da Estação de Tratamento de Esgoto de Brasília - Asa Sul - Anos de 2019 e 2020.( Database of the Sewage Treatment Plant of Brasilia Asa Sul - Years 2019 and 2020). Brasília, DF, Brazil: CAESB - Companhia de Saneamento do Distrito Federal. 2021.

CAMPOS, J. R.; POVINELLI, S. C. S.; AISSE, M. M.; SOUZA, M. A. A.; SAMWAYS, G.; ALEM SOBRINHO, $P$. Tratamento combinado de lodo de fossa e tanque séptico com esgoto (Combined treatment of septage with sewage). In: Andreoli, C. V. (Coord). Lodo de fossa e tanque séptico: caracterização, tecnologias de tratamento, gerenciamento e destino final (Septage: characterization, treatment technologies, management and final destination). ABES, Curitiba, PR, Brazil: ABES. Programa de Pesquisa em Saneamento Básico PROSAB. p. 181-282. Available at: https://www.finep.gov.br/images/apoio-e-

financiamento/historico-de-

programas/prosab/prosab5 tema 6.pdf. 2009.

ROHILLA, S. K.; LUTHRA, B.; BHATNAGAR, A.; MATTO. M.; BHONDE, U. Septage Management: A Practitioner's Guide. New Delhi, India: Centre for Science and Environment, Ministry of Urban Development, Government of India. 2017.

DISTRITO FEDERAL Decreto No 18.328 de 8 de junho de 1997 - Título IV: Sobre a descarga de efluentes 
líquidos na rede de esgotos (Decree 18,328 of June 8, 1997 - Title IV: On the discharge of liquid effluents into the sewage collection network). Brasília, DF, Brazil: Diário Oficial do Distrito Federal. 19 de junho de 1997 (Published in the Official Gazette of the Federal District of Brazil on June 19, 1997). p. 4385. Available at: https://www.caesb.df.gov.br/empresa/legislaca01/decre tos/407-decreto-18330.html. 1997.

GASPERI, R. L. P. Caracterização de resíduos de caixa de gordura e avaliação como alternativa para o prétratamento. Dissertação de Mestrado. (Characterization of grease traps residues and evaluation as an alternative for pre-treatment. Masters dissertation). São Carlos, SP, Brazil: Escola de Engenharia de São Carlos. Universidade de São Paulo - EESC - USP. 97p. Available

at: https://www.teses.usp.br/teses/disponiveis/18/18138/td e-12062013-145456/pt-br.php. 2012.

GOWTHAMAN, S.; MAFIZUR, R.; SIVAKUMAR, S. S. Performance evaluation of waste water treatment plant: an analysis of FOG removal efficiency. International Journal of Scientific \& Engineering Research. V. 8, Issue 1, January 2017. pp. 2084-2089. ISSN 2229-5518. Available at: http://www.ijser.org. 2017.

HUSAIN, I. A. F.; ALKHATIB, M. F.; JAMMI, M.S.; MIRGHANI, M. E. S.; ZAINUDIN, Z. B.; HODA, A. problems, control, and treatment of fat, oil, and grease (FOG): A Review. Journal of Oleo Science. 63, (8) 747752 (doi:10.5650/jos.ess13182). 2014.

LEVINE, D. M.; STEPHAN, D.; KREHBIEL, T. C.; BERENSON, M. L. Statistics for managers: using Microsoft Excel. Fifth Edition. New Jersey, USA: Pearson Education Inc./ Prentice Hall. 752p. 2008.

LOPEZ-VAZQUEZ, C. M.; DANGOL, B.; HOOIJMANS C. M.; BRDJANOVIC, D. Chapter 9 - Co-treatment of Faecal Sludge in Municipal Wastewater Treatment Plants. IN: Linda Strande; Mariska Ronteltap; Damir Brdjanovic Faecal sludge management systems approach for implementation and operation. London,
UK: IWA Publishing. p. 177-202. Available at: https://doi.org/10.2166/9781780404738. ISBN electronic: 9781780404738 https://iwaponline.com/ebooks/book/384/FaecalSludge-Management-Systems-Approach-for. 2014.

NARAYANA, D. Septage and fecal sludge in sewage treatment facilities: a guide for planners and implementers. London, UK: IWA Publishing. 77p. Available at: https://doi.org/10.2166/9781789061277. 2020.

SANTANDER, M.; RODRIGUES, R.; RUBIO, J. Remoción de aceites (petróleo) emulsificados en agua por floculación-flotación (Removal of oils (petroleum) emulsified in water by flocculation-flotation jet). Revista de La Faculdad de Ingenieria. Universidad de Atacama. Vol. 24. p.33-40. Available at: http://www.revistaingenieria.uda.cl/. 2010.

SILVA, A. D.; SILVA, L. C. P.; FIRMINO, F. M.; FREITAS, M.; GINORIS, Y. P. Caracterização de resíduos de caminhões limpa-fossas no Distrito Federal (Characterization of waste from septage trucks in the Federal District of Brazil). IN: XXVIII CONGRESSO BRASILEIRO DE ENGENHARIA SANITÁRIA E AMBIENTAL. Rio de Janeiro,RJ, Brazil: ABES Associação Brasileira de Engenharia Sanitária e Ambiental, 10p. Available at: http://abesdn.org.br/28cbesa/. 2015.

TAYLER, K. Faecal sludge and septage treatment: A guide for low- and middle-income countries. Rugby, UK, Practical Action Publishing, http://dx.doi.org/10.3362/ 9781780449869. 2018.

WEF - WATER ENVIRONMENT FEDERATION. Industrial wastewater, management, treatment, and disposal. manual of practice No. FD-3. $3^{\text {rd }}$ edition. Alexandria, USA: WEF. 602p. 2008.

WILLIAMS, T. O.; GABEL, D.; ROBILLARD, D. FOG waste receiving and processing facility design considerations. Water Practice \& Technology, V. 13, No 1. (doi: 10.2166/wpt.2018.023). 2018. 